DOI: https://doi.org/10.31933/dijdbm.v2i3

Received: 22 Febuary 2021, Revised: 18 March 2021, Publish: 18 March 2021

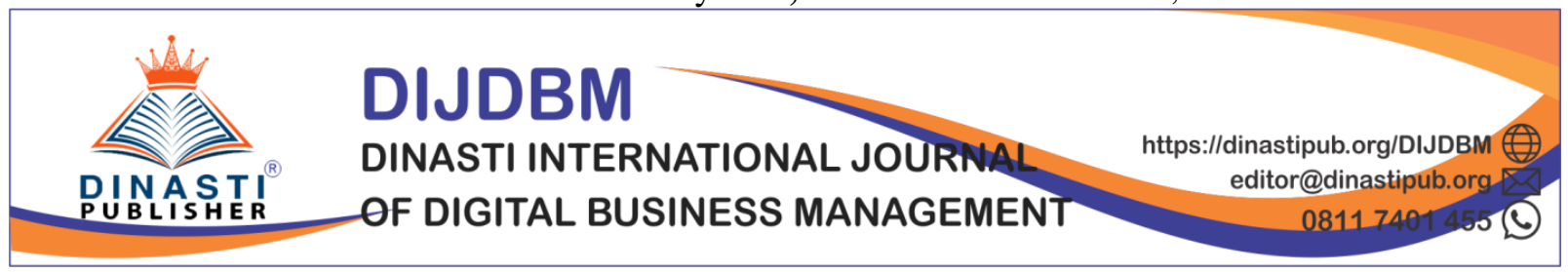

\title{
PURCHASE INTENTION AND PURCHASE DECISION MODEL: MULTI CHANNEL MARKETING AND DISCOUNT ON MEDCOM.ID ONLINE NEWS PORTAL
}

\author{
Nasikhul Amin Al Hafizi ${ }^{1}$, Hapzi Ali ${ }^{2}$ \\ 1) Mahasiswa Program Magister Management, Universitas Mercu Buana, Jakarta, email: \\ na.alhafizi@gmail.com \\ 2) Dosen Program Magister Management, Universitas Mercu Buana, Jakarta, email. \\ hapzi.ali@mercubuana.ac.id
}

\begin{abstract}
This study aims to determine the effect of multi-channel marketing and discount / saving value on purchasing decisions through clients' buying interest in advertising services provided by Medcom.id. The numbers of respondents involved in this study were 85 respondents. All respondents are clients (agencies or companies) who have advertised on Medcom.id. The data in this study were analyzed quantitatively using the Partial Least Square technique with the help of the Smartpls program. The research results are: (1) Multichannels marketing has a positive effect on the purchase interest of prospective clients, the better the multi-channel marketing conducted by Medcom.id, the higher the buying interest of prospective clients to advertise on Medcom.id; (2) Discount has a positive and significant effect on consumer buying interest, the more attractive the discount Medcom.id offers, the higher the buying interest of potential clients to advertise on Medcom.id; (3) Multi-channels marketing has a positive effect on client purchasing decisions, the better the multi-channel marketing conducted by Medcom.id, the higher the purchasing decisions of prospective clients to advertise on Medcom.id; (4) Discount has a positive and significant effect on consumer purchasing decisions, the more attractive the discount offered by Medcom.id, the higher the purchasing decisions of prospective clients to advertise on Medcom.id; (5) Purchasing interest affects consumer purchasing decisions, prospective clients with high buying interest tend to have high purchasing decisions for advertising services offered by Medcom.id; (6) Purchasing interest can mediate the effect of multi-channels marketing on purchasing decisions, the better multi-channels marketing will increase client's buying interest which in turn will improve purchasing decisions; (7) Purchase interest can mediate the effect of discount on purchasing decisions, giving discounts that attract prospective clients will increase prospective clients' buying interest which in turn will increase client purchasing decisions.
\end{abstract}

Keyword: multi-channels marketing, discount / saving value, buying interest, purchasing decisions, online media 


\section{INTRODUCTION}

The increased advertising expenditure (advertising expenditure) that is broadcast on online media has become a magnet for capital owners to invest in the online media business. This is marked by the birth of thousands of online media sites spread on the internet. Based on data reported by (Dewan Pers, 2017), at least 47,300 online media currently exist in Indonesia. Competition between online media is so tight in getting advertisers is a tough challenge for media companies because companies must be able to determine an effective advertising strategy in order to get a large income from ad sales. One of the online media that has experienced the intense competition in the online media industry in Indonesia is Medcom.id.

In total revenue in 2019, there is a gap between Medcom.id's target and realization of company revenue. Medcom.id only succeeded in achieving $74 \%$ of the company's target. In an effort to achieve the company's target, Medcom.id has made various efforts to attract advertisers to buy advertisements on Medcom.id.

From the results of the pre-survey that the researchers conducted before, the researchers found that there are two main factors that increase the interest in buying advertiser advertisements at Medcom.id, namely multi-channel marketing \& discounts or what is also called the saving value provided by Medcom.id. According to Kotler in (Stojković et al., 2016) explaining multi-channel marketing is a situation where a company uses two or more channels to reach one or more market segments. (Suharno \& Yudi Sutarso, 2010) defines that a discount is a direct reduction in the price of purchases for a certain period.

\section{EMPIRICAL STUDY}

Based on several recent studies, it is stated that there is a research gap that needs to be considered related to purchase interest and purchasing decisions, as stated by (Mahendrayasa, 2014) which states that there is a significant and positive relationship between purchase intention and purchase decision. However, different things are expressed by (Montjai, O., Tewal, B., \& Lengkong, 2014) in his research that buying interest does not have a partial effect on purchasing decisions.

Research gaps were also found related to the effect of discounts on purchasing decisions. According to (Endhar Widjaya Putra, 2014) saying that discounts have no significant effect on purchasing decisions, while on the other hand, as stated by (Dewi \& Kusumawati, 2018) states that discounts or price discounts have a significant positive effect on purchasing decisions.

\section{Formulation of The Problem}

Based on the background described above, the problems that will be discussed are formulated to focus more on literature review, the results and discussion are as follows:

1) How does Discount affect purchase interest in Medcom.id online media?

2) How is the effect of multi-channel marketing on purchasing interest in Medcom.id's online media?

3) How does Discount affect purchasing decisions on online media Medcom.id?

4) How is the effect of multi-channel marketing on purchasing decisions on Medcom.id's online media? 
5) How does purchase intention influence purchasing decisions on Medcom.id's online media?

6) How does Discount affect purchasing decisions on Medcom.id online media through purchase intention?

7) How does multi-channel marketing affect purchasing decisions on Medcom.id's online media through purchase intention?

\section{LITERATURE REVIEW \\ Purchase Intention}

Purchase interest according to (P. and G. A. Kotler, 2012) is something that arises after receiving stimulation from a product that he sees, then the desire to buy and own it arises. Research on buying interest has been widely studied in books and previous research such as books and research developed by (Ardiansyah, 2012), (Rivan Kojongian, Joyce Lapian, 2019), (P. and G. A. Kotler, 2012), (Yunita \& Ali, 2017), (Ali, 2019a),(Brata et al., 2017), (Anggita \& Ali, 2017), (Thanh Nguyen et al., 2019), (Novansa \& Ali, 1926), (Mappesona et al., 2020)(Ali, Evi, et al., 2018), and (Ali, Narulita, et al., 2018) etc.

\section{Purchase Decision}

The purchase decision according to (Kotler, Philip., Keller, 2013) is a consumer's decision to buy after evaluating several factors such as brand, location of purchase, amount to be purchased, time of purchase, and methods of payment that can be made. Research on purchasing decisions has been widely studied in books and previous research such as books and research developed by (Richardo et al., 2020), (Ali, Evi, et al., 2018), (Ikhsani \& Ali, 2017), (Ali, Evi, et al., 2018), (Mappesona et al., 2020), (Novansa \& Ali, 2017), (Thanh Nguyen et al., 2019), dll.

\section{Multi Channels Marketing}

According to (Balter, 2015) multi-channel marketing is a strategy to reach prospects and customers through various platforms or communication channels. (Kotler, P. \& Keller, 2009) in (Stojković et al., 2016) defines multi-channel marketing as a situation in which "a company uses two or more marketing channels to reach one or more market segments". Multi channel marketing research has also been widely reviewed in previous studies such as research conducted by (Rangaswamy, A. \&Van Bruggen, 2005), (Chen, 2015), (Schijns \& Nederland, 2014), (Hobmeier, 2001), (P. Kotler, 2000), (Rollo, 2004), (Schögel, M. and Sauer, 2002), (Kelly, 2004), (Rollo, 2004), (Schögel, M. and Sauer, 2002), (Easingwood, C. and Storey, 1996), (P. Kotler, 2000), (Schögel, M. and Sauer, 2002), (Pucci et al., 2019).

\section{Discount / Saving Value}

Kotler in (Tjiptono, 2014) explains that a discount is a basic price adjustment to reward customers for certain reactions, such as earlier payment times, the level and number of purchases and purchases in certain seasons. Research on discount / saving value has also been widely studied in previous studies such as research conducted by (Sundalangi et al., 2014), (Citra Kunia putri dan trisna insan Noor, 2013b), (Dewi \& Kusumawati, 2018), (Suharno \& Yudi Sutarso, 2010).

\section{Conceptual Framework}

Based on the relationship between variables in the previous research review, the researcher made it the basis for building a conceptual framework, as shown in the following figure. 
Figure 1. Conceptual Framework

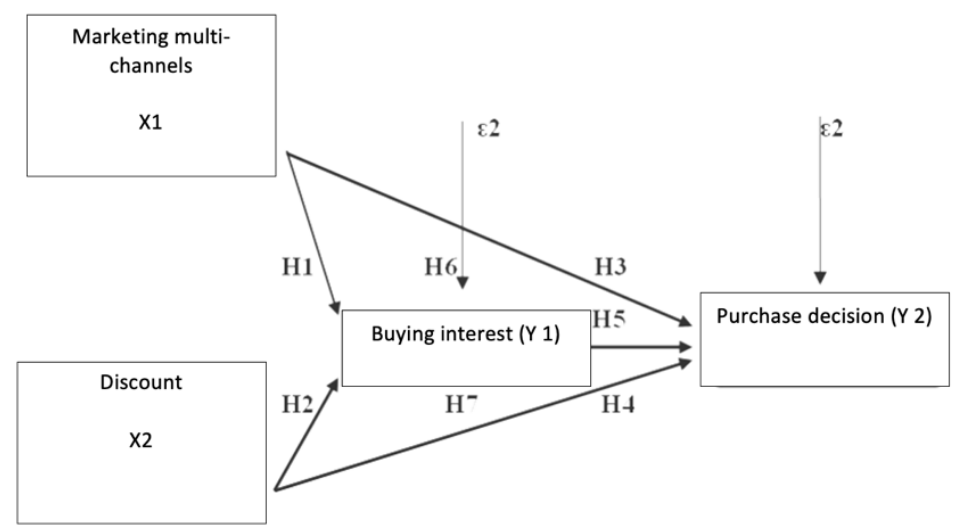

\section{Hypothesis}

H1: Multi Channels marketing has a positive \& significant effect on purchase intention.

H2: Discount has a positive \& significant effect on purchase intention.

H3: Multi Channels Marketing has a positive \& significant effect on purchasing decisions.

H4: Discount has a positive \& significant effect on purchasing decisions.

H5: Purchase intention has a positive \& significant effect on purchasing decisions.

H6: Multi Channels marketing has a positive \& significant effect on purchasing decisions, through purchase intention.

H7: Discount has a positive \& significant effect on purchasing decisions, through purchase intention.

\section{Population And Sample}

The population in this study, were institutions, companies and advertising agency companies advertising on online media Medcom.id for the period 2019-2020, amounting to 293 clients. The sampling technique in this study used purposive sampling, determining the sample with certain considerations. Determination of the sample size of respondents using the Slovin formula. Based on calculations using the Slovin formula, the sample size (n) in this study was 74.55 people or rounded to 75 Medcom.id clients for the period 2019-2020 which will be used as the sample size of the study.

\section{Measurement and Data Collection}

Variable measurement is a measuring tool used to quantify the information provided by consumers if they are required to answer questions that have been formulated in a questionnaire (Noor, 2011). The measurement scale that researchers used in this study was the Likert scale. Data collection in this study was carried out through primary data collection using a questionnaire or questionnaire.

\section{Data Analysis Method}

The data analysis method in this study uses component or variance based Structural Equation Modeling (SEM) where the data processing uses the Smart-Partial Least Square (Smart-PLS) version 3.0 program. PLS (Partial Least Square) is a model of variance based SEM. PLS is intended for causal-perdictive analysis in situations of high complexity and low theory support (Ghozali, 2014). According to (Ghozali, 2014) the test steps carried out are as follows: evaluation of measurement (outer models) and testing of structural models or testing of hypotheses (inner model). 


\section{RESULTS AND DISCUSSION}

Result

In this study, the direct effect significance test was used to test the effect of exogenous variables on endogenous variables. The hypothesis used in this test is as follows:

Ho: exogenous variables do not have a positive effect on endogenous variables Ha: exogenous variables have a positive effect on endogenous variables.

Because the research hypothesis is a one-way hypothesis, Ho is rejected and it is concluded that exogenous variables have a significant effect on endogenous variables if the $P$ value $<0.05$ and $t$ count $>1.65$, whereas if the $p$ value $>0.05$ and $t$ count $<1,65$ then Ho is not rejected and it is concluded that exogenous variables have no effect on endogenous variables. The full significance test results of this direct effect can be seen in the following table:

Table 1. Partial Effect Testing Results

\begin{tabular}{|c|c|c|c|c|c|}
\hline & $\begin{array}{c}\text { Original } \\
\text { Sample } \\
(\mathrm{O})\end{array}$ & $\begin{array}{c}\text { Sample } \\
\text { Mean } \\
(\mathrm{M})\end{array}$ & $\begin{array}{c}\text { Standard } \\
\text { Deviation } \\
(\mathrm{STDEV})\end{array}$ & $\begin{array}{c}\text { T Statistics } \\
(\mid \mathrm{O} / \mathrm{STDEV})\end{array}$ & P Values \\
\hline DI -> KEP & 0.185 & 0.175 & 0.091 & 2.023 & $\mathbf{0 . 0 4 4}$ \\
\hline DI -> MB & 0.512 & 0.515 & 0.070 & 7.349 & $\mathbf{0 . 0 0 0}$ \\
\hline MB -> KEP & 0.490 & 0.495 & 0.102 & 4.793 & $\mathbf{0 . 0 0 0}$ \\
\hline PMC -> KEP & 0.311 & 0.313 & 0.072 & 4.342 & $\mathbf{0 . 0 0 0}$ \\
\hline PMC -> MB & 0.337 & 0.337 & 0.072 & 4.693 & $\mathbf{0 . 0 0 0}$ \\
\hline
\end{tabular}

In this study also looked at the indirect influence, purchase interest as a variable that mediates the effect of discount and multi-channel marketing on purchasing decisions. To test the role of purchase interest in mediating the effect of discount and multi-channel marketing on purchasing decisions, an indirect effect test is performed with the following hypothesis testing:

Ho: Purchasing interest cannot mediate the effect of discount or multi-channel marketing on purchasing decisions

Ha: Purchasing interest can mediate the effect of discount or multi-channel marketing on purchasing decisions

With a significance level of $5 \%$, Ho is rejected if the $\mathrm{p}$ value is $<0.05$ and Ho is not rejected if the $\mathrm{p}$ value is $>0.05$. The full significance test results of this indirect effect can be seen in the following table:

Table 2. Indirect Effect Testing Result

\begin{tabular}{|c|c|c|c|}
\hline & $\begin{array}{c}\text { Original } \\
\text { Sample }(\mathbf{O})\end{array}$ & $\begin{array}{c}\text { T Statistics } \\
(\mid \text { O/STDEV })\end{array}$ & P Values \\
\hline DI -> MB -> KEP & 0.251 & 3.451 & $\mathbf{0 . 0 0 1}$ \\
\hline PMC -> MB -> KEP & 0.165 & 3.489 & $\mathbf{0 . 0 0 1}$ \\
\hline
\end{tabular}




\section{DISCUSSION}

1) The effect of multi-channel marketing on purchase interest

In this study, it is stated that multi-channel marketing has a positive effect on purchase interest. The results of the analysis in this study indicate that on the path of the effect of multi-channels marketing on purchase interest (PMC $\rightarrow \mathrm{MB}$ ), the p value obtained is 0.000 with a T statistic of 4.693 and the path coefficient is positive at 0.337 . Because the path p-value $<0.05$, T statistic $>1.65$ and the path coefficient is positive, it can be concluded that multi-channels marketing has a positive and significant effect on purchase interest, this indicates that the better multi-channels marketing is, the higher interest in purchasing prospective clients who will use advertising services at Medcom.id.

The results of this study are in line with the results expressed in research (Pucci et al., 2019) which states that the use of various online media (multi channels) shows an important role in the purchasing process, and the effective use of media will be able to help increase sales.

2) The effect of discount on purchase interest

In this study states that, the discount has a positive effect on purchase interest. The results of the analysis in this study show that on the path that shows the effect of discount / saving value on purchase intention (DI $->\mathrm{MB}$ ), the $\mathrm{p}$ value obtained is 0.000 with a $\mathrm{T}$ statistic of 7.349 and the path coefficient is positive at 0.512 . Because the path $p$ value $<0.05$, $\mathrm{T}$ statistic $>1.65$ and the path coefficient is positive, it can be concluded that discount has a positive and significant effect on purchase interest.

With this, it can be stated that the better the discount offered to prospective clients, the higher the purchase interest of prospective clients who will advertise on Medcom.id. The results of this study are in line with the results of research (Sundalangi et al., 2014) which states that price discounts have an effect on consumer buying interest. The same thing was conveyed by (Citra Kunia putri dan trisna insan Noor, 2013a) discount has a positive and significant effect on consumer buying interest. The higher the discount, the higher purchase interest of clients.

3) The effect of multi-channel marketing on purchasing decisions

In this study, it was found that multi-channel marketing has a positive effect on purchasing decisions. The results of the analysis in this study show that on the path that shows the effect of multi-channel marketing on purchasing decisions (PMC -> KEP), the $p$ value obtained is 0.000 with a T statistic of 4.342 and the path coefficient is positive at 0.311 . Because the path p-value $<0.05$, T statistic $>1.65$ and the path coefficient is positive, it can be concluded that multi-channel marketing has a positive and significant effect on purchasing decisions. In other words, the better the multi-channel marketing, the higher the purchasing decisions of prospective clients.

The results of this study are in line with the results of research (Pucci et al., 2019) which states that the use of various online media (social media) shows an important role in the buying process, as well as the effective use of media will be able to help increase sales. In other words, the use of various social media positively affects consumer purchasing decisions which ultimately results in increased sales.

4) The effect of discount on purchasing decisions 
In this study states that, the discount has a positive effect on purchasing decisions. The results of the analysis in this study indicate that on the path that shows the effect of discount on purchasing decisions (DI -> KEP), the $\mathrm{p}$ value obtained is 0.044 with a $\mathrm{T}$ statistic of 2.023 and the path coefficient is positive at 0.185 because the path $\mathrm{p}$ value is $<0,05, \mathrm{~T}$ statistic> 1.65 and the path coefficient is positive, it can be concluded that the discount has a positive and significant effect on purchasing decisions, this indicates that the better the discount, the higher the purchasing decisions of prospective clients. The results of this study are in line with the results of research (Dewi \& Kusumawati, 2018), (Novansa, Hafizh, Ali, 2017) and (Richardo et al., 2020) which state that the discount variable has a significant effect on purchasing decisions. The more discount prices offered will increase the purchasing power of consumers.

5) The influence of purchase intention on purchasing decisions

In this study states that purchase interest has a positive effect on purchasing decisions. The results of the analysis in this study show that on the path that shows the effect of buying interest on purchasing decisions (MB-> KEP), the $\mathrm{p}$ value obtained is 0.000 with a $\mathrm{T}$ statistic of 4.793 and the path coefficient is positive at 0.490 . Because the path p-value <0.05, T statistic $>1.65$ and the path coefficient is positive, it can be concluded that purchase interest value has a positive and significant effect on purchasing decisions, this indicates that the better the purchase intention, the higher the purchase decision. The results of this study are in line with research (Ali, 2019b) which states that the purchase interest variable has a significant effect on purchasing decisions.

6) The role of purchasing interest in mediating the effect of multi-channel marketing on purchasing decisions

In this study states that purchase interest can mediate the effect of multi-channel marketing on purchasing decisions. The results of the analysis in this study indicate that the $p$ value of the indirect effect of multi-channel marketing on purchasing decisions mediated by buying interest is 0.001 , because the $p$ value of the indirect effect is $<0.05$ and it is concluded that buying interest can mediate the effect of multi-marketing. channels against purchase decisions.

The mediation factor of purchasing interest on the effect of multi-channel marketing on purchasing decisions is partial mediation, this is because without purchasing interest, good multi-channel marketing can directly improve the purchasing decisions of prospective clients.

7) The role of purchase interest in mediating the effect of discount on purchasing decisions

In this research states that purchase interest can mediate the effect of discount on purchasing decisions. The results of the analysis in this study indicate that the $\mathrm{p}$ value of the indirect effect of doscount on purchasing decisions mediated by buying interest is 0.001, because the $\mathrm{p}$ value of the indirect effect is $<0.05$, Ho is rejected and it is concluded that purchase interest can mediate the effect of discount on purchasing decisions.

The mediation factor of purchasing interest on the effect of discount on purchasing decisions is partial mediation, this is because without buying interest, good and attractive discounting will directly increase the purchasing decisions of prospective clients. 


\section{CONCLUSIONS AND SUGGESTIONS Conclusion}

Based on the formulation of the article, the results and discussion that are reviewed and discussed in this article, it can be concluded that:

1) Multi-channel marketing has a positive effect on consumer purchasing interest, the better the multi-channel marketing conducted by Medcom.id, the higher the purchasing interest of prospective clients to advertise on Medcom.id

2) Discount has a positive and significant effect on consumer purchase interest, the more attractive the discount Medcom.id offers, the higher the purchase interest of prospective clients to advertise on Medcom.id

3) Multi-channel marketing has a positive effect on consumer purchasing decisions, the better the multi-channel marketing conducted by Medcom.id, the higher the purchasing decisions of prospective clients to advertise on Medcom.id

4) Discounts have a positive and significant effect on consumer purchasing decisions, the more attractive the discounts Medcom.id offers, the higher the purchasing decisions of prospective clients to advertise on Medcom.id

5) Purchase interest affects consumer purchase decisions, prospective clients with high buying interest tend to have high purchasing decisions for the advertising services offered by Medcom.id.

6) Purchase interest can mediate the effect of multi-channel marketing on purchasing decisions, good multi-channel marketing will increase the buying interest of potential clients to use advertising services at Medcom.id which will further increase consumer purchasing decisions on advertising services offered by Medcom.id.

7) Purchase interest can mediate the effect of discount on purchasing decisions, giving discounts that attract prospective clients will increase potential clients' buying interest to use advertising services at Medcom.id which will further increase consumer purchasing decisions on advertising services offered by Medcom.id.

\section{Suggestion}

Suggestions that can be conveyed from the results of this study are as follows:

For Medcom.id

a. The results of the analysis in this study indicate that multi-channel marketing and discounting turn out to be very influential factors on the purchase interest and purchase decisions of prospective clients who will use advertising services at Medcom.id, this means that buying interest and purchasing decisions of prospective clients are high, then Medcom.id should be able to provide the best service so that multi-channel marketing through Medcom.id is really beneficial for clients and the discount given can attract prospective clients.

b. In this study, it was found that the discount indicator, which was given at a certain time, got a relatively lower point than other indicators on the discount variable, although it is still quite good, the researchers can suggest that in the future Medcom.id can maximize the marketing discount agenda on calendar events / or discount days. 
special days every month to be able to increase purchase interest and purchase decisions from advertisers.

c. In the analysis of this research, it was found that the marketing indicators through the Media Group News sales team \& various channels received relatively lower scores even though they were still relatively good, but on the other hand this meant that the Medcom.id team needed to maximize the Media Group News sales team in providing information services. for clients or advertisers.

d. Medcom.id needs to further increase the use of various platforms to establish relational communication with advertisers.

\section{For further research}

Further research can carry out research by adding other variables outside the variables that have been studied in this study but can have an impact on purchase interest and consumer purchasing decisions. Other variables include the quality of advertising services, the price of advertising services and the quality of services, and so on.

\section{REFERENCES}

Ali, H. (2019a). Building Repurchase Intention and Purchase Decision: Brand Awareness and Brand Loyalty Analysis (Case Study Private Label Product in Alfamidi Tangerang). Saudi Journal of Humanities and Social Sciences. https://doi.org/10.36348/sjhss.2019.v04i09.009

Ali, H. (2019b). Purchase Decision and Repurchase Models: Product Quality and Process Analysis (Case Study of House Ownership Credit Financing in Permata Sharia Bank Jakarta). Scholars Bulletin. https://doi.org/10.36348/sb.2019.v05i09.006

Ali, H., Evi, N., \& Nurmahdi, A. (2018). The Influence of Service Quality , Brand Image and Promotion on Purchase Decision at MCU Eka Hospital. Business and Management Studies. https://doi.org/10.21276/sjbms.2018.3.1.12

Ali, H., Narulita, E., \& Nurmahdi, A. (2018). Saudi Journal of Business and Management Studies ( SJBMS ) The Influence of Service Quality, Brand Image and Promotion on Purchase Decision at MCU Eka Hospital. Business and Management Studies. https://doi.org/10.21276/sjbms.2018.3.1.12

Anggita, R., \& Ali, H. (2017). The Influence of Product Quality, Service Quality and Price to Purchase Decision of SGM Bunda Milk (Study on PT. Sarihusada Generasi Mahardika Region Jakarta, South Tangerang District). Scholars Bulletin. https://doi.org/10.21276/sb

Ardiansyah, M. A. (2012). Pengaruh Kualitas Produk Terhadap Minat Pembelian Serta Dampaknya Terhadap Proses Keputusan Pembelian J\&C Cookies.

Balter, S. (2015). Multi-Channel Marketing.

Brata, B. H., Husani, S., \& Ali, H. (2017). The Importance of Quality Products, Price, Promotion, and Location to Product Purcese Decision on Nitchi At PT. Jaya Swarasa Agung in Central Jakarta. Saudi Journal of Business and Management Studies. https://doi.org/10.21276/sjbms

Chen, S. (2015). Multichannel Marketing: a Generalized Framework, and the Antecendents and Consequences of Its Implementation. March, 1-124.

Citra Kunia putri dan trisna insan Noor, 2011. (2013a). PENGARUH KUALITAS PRODUK, DAYA TARIK IKLAN, DAN POTONGAN HARGA TERHADAP MINAT BELI KONSUMEN PIZZA HUT DI KOTA MALANG. PENGARUH KUALITAS PRODUK, DAYA TARIK IKLAN, DAN POTONGAN HARGA TERHADAP MINAT BELI KONSUMEN PIZZA HUT DI KOTA MALANG Karina, 53(9), 1689-1699.

Citra Kunia putri dan trisna insan Noor, 2011. (2013b). 済無No Title No Title. Analisis 
Pendapatan Dan Tingkat Kesejahteraan Rumah Tangga Petani, 53(9), 1689-1699.

Dewan Pers. (2017). Mendorong Profesionalisme Pers melalui verifikasi Perusahaan Pers. Jurnal Dewan Pers, 14.

Dewi, I. K., \& Kusumawati, A. (2018). Pelanggan Bisnis Online ( Survei pada Mahasiswa Fakultas Ilmu Administrasi Universitas Brawijaya Angkatan 2013 / 2014 Konsumen Traveloka ). Jurnal Administrasi Bisnis, 56(1), 155-163. administrasibisnis.studentjournal.ub.ac.id\%0A163

Easingwood, C. and Storey, C. (1996). "The Value of Multi-Channel Distribution Systems in the Financial Services Sector." The Services Industries Journal, Vol. 16, N, 223-241.

Endhar Widjaya Putra, 2014. (2014). Pengaruh Diskon Terhadap Minat Beli Serta Dampaknya pada Keputusan Pembelian (Survey pada Konsumen yang Membeli Produk Diskon di Matahari Department Store Pasar Besar Malang). Engaruh Diskon Terhadap Minat Beli Serta Dampaknya Pada Keputusan Pembelian (Survey Pada Konsumen Yang Membeli Produk Diskon Di Matahari Department Store Pasar Besar Malang).

Ghozali, I. (2014). Structural Equation Modeling, Konsep, dan Aplikasi Dengan Program Partial Least Square (Edisi 4). Badan Penerbit Universitas Diponegoro.

Hobmeier, M. (2001). "Professional multichannel management."

Ikhsani, K., \& Ali, D. H. (2017). Keputusan Pembelian: Analisis Kualitas Produk, Harga dan Brand Awareness (Studi Kasus Produk Teh Botol Sosro di Giant Mall Permata Tangerang). In Jurnal SWOT.

Kelly, M. (2004). "One to many, through many."

Kotler, P. \& Keller, K. (2009). Marketing Management, 13th Edition. Prentice Hall.

Kotler, Philip., Keller, K. L. (2013). Manajemen Pemasaran, Jilid Kedua. Erlangga.

Kotler, P. (2000). Marketing Management, 10th International Edition, Prentice Hall, Upper Saddle River, pp. 507-509.

Kotler, P. and G. A. (2012). Prinsip-prinsip Pemasaran (Edisi. 13.). Erlangga.

Mahendrayasa, A. (2014). PENGARUH WORD OF MOUTH TERHADAP MINAT BELI SERTA DAMPAKNYA PADA KEPUTUSAN PEMBELIAN (Survei pada Mahasiswa Pengguna Kartu Selular GSM âIM3â Angkatan 2011/2012 dan 2012/2013 Fakultas Ilmu Administrasi Universitas Brawijaya Malang). Jurnal Administrasi Bisnis S1 Universitas Brawijaya, 12(1), 82799.

Mappesona, H., Ikhsani, K., \& Ali, H. (2020). Customer purchase decision model, supply chain management and customer satisfaction: Product quality and promotion analysis. International Journal of Supply Chain Management.

Montjai, O., Tewal, B., \& Lengkong, P. . V. (2014). Motivasi, Sikap, Dan Minat Beli Konsumen Pengaruhnya Terhadap Keputusan Pembelian Sepeda Motor Yamaha Pt. Hasjrat Abadi Sentral Yamaha Manado.

Noor, J. (2011). Metodologi Penelitian: Skripsi, Tesis, Disertasi, \& Karya Ilmiah. Prenada Media Group.

Novansa, Hafizh, Ali, H. (2017). Purchase Decision Model: Analysis of Brand Image, Brand Awareness and Price (Case Study SMECO Indonesia SME products). Saudi Journal of Humanities and Social Sciences.

Novansa, H., \& Ali, H. (1926). Purchase Decision Model: Analysis of Brand Image, Brand Awareness and Price (Case Study SMECO Indonesia SME products). Saudi Journal of Humanities and Social Sciences. https://doi.org/10.21276/sjhss

Novansa, H., \& Ali, H. (2017). Purchase Decision Model: Analysis of Brand Image, Brand Awareness and Price (Case Study SMECO Indonesia SME products). Saudi Journal of Humanities and Social Sciences. https://doi.org/10.21276/sjhss

Pucci, T., Casprini, E., Nosi, C., \& Zanni, L. (2019). Does social media usage affect online 
purchasing intention for wine? The moderating role of subjective and objective knowledge. British Food Journal, 121(2), 275-288. https://doi.org/10.1108/BFJ-062018-0400

Rangaswamy, A. \&Van Bruggen, G. (2005). Opportunities and challenges in multichannel marketing: An introduction to the special issue. Journal of Interactive Marketing.

Richardo, Hussin, M., Bin Norman, M. H., \& Ali, H. (2020). A student loyalty model: Promotion, products, and registration decision analysis-Case study of griya english fun learning at the tutoring institute in wonosobo central Java. International Journal of Innovation, Creativity and Change.

Rivan Kojongian, Joyce Lapian, H. T. P. (2019). Analisis Pengaruh Word Of Mouth, Iklan Dan Citra Merek Terhadap Keputusan Pembelian Melalui Minat Beli Sebagai Variabel Intervening Pada Smartphone Xiaomi Manado. Jurnal Riset Bisnis \& Manajemen, 7.

Rollo, C. (2004). "Seniors, Teens, and Everyone Tween: Selecting service channels to fit customer demographics."

Schijns, J. M. C., \& Nederland, O. U. (2014). Multi-channel Management: Getting it Right! Multi-channel Management: Getting it Right! Jos Schijns Kees Groenewoud. June 2006.

Schögel, M. and Sauer, A. (2002). "Multi-Channel Marketing - Die Königsdisziplin im CRM."

Stojković, D., Lovreta, S., \& Bogetić, Z. (2016). Multichannel strategy - The dominant approach in modern retailing. Economic Annals, 61(209), 105-127. https://doi.org/10.2298/EKA1609105S

Suharno \& Yudi Sutarso. (2010). Marketing in Practice. Graha Ilmu.

Sundalangi, M., Mandey, S. L., Jorie, R. J., Produk, K., Produk, K., Iklan, D. T., Potongan, D. A. N., \& Terhadap, H. (2014). KUALITAS PRODUK, DAYA TARIK IKLAN, DAN POTONGAN HARGA TERHADAP MINAT BELI KONSUMEN PADA PIZZA HUT MANADO. KUALITAS PRODUK, DAYA TARIK IKLAN, DAN POTONGAN HARGA TERHADAP MINAT BELI KONSUMEN PADA PIZZA HUT MANADO, 2(1), 313-324.

Thanh Nguyen, P., Ali, H., \& Agung Hudaya. (2019). MODEL BUYING DECISION AND REPEAT PURCHASE: PRODUCT QUALITY ANALYSIS (Case Study of Bank Permata Syariah Jakarta KPR Financing Customers). Dinasti International Journal of Management Science. https://doi.org/10.31933/dijms.v1i1.29

Tjiptono, F. (2014). Pemasaran Jasa - Prinsip, Penerapan, dan Penelitian.

Yunita, D., \& Ali, H. (2017). Model of Purchasing Decision ( Renting ) of Generator Set: Analysis of Product Quality, Price an Service at PT . Hartekprima Listrindo. Economics, Business and Management. https://doi.org/10.21276/sjebm.2017.4.11.12 